\title{
New data on celestine-rich salts in the Wieliczka salt deposits
}

\author{
Justyna Nowińska \\ AGH University of Science and Technology, Faculty of Geology, Geophysics and Environmental Protection; \\ al. A. Mickiewicza 30, 30-059 Krakow, Poland; e-mail: justyna.k.nowinska@gmail.com
}

(C) 2017 Authors. This is an open access publication, which can be used, distributed and reproduced in any medium according to the Creative Commons CC-BY 4.0 License requiring that the original work has been properly cited.

Received: 2017-04-27; accepted: 2017-05-18

\begin{abstract}
Pale brownish celestine-rich salt rocks were found near the Franciuszek Müller gallery, in the chambers of the 3rd level in the Wieliczka Salt Mine. The complex of rock salts subjected to exploration occurred within a large seam approximately $15 \mathrm{~m}$ thick. Detailed research revealed that the salt has the form of a block incorporated within the gray salts body and being similar to other blocks of green salts, well known in the upper part of the deposit. A characteristic petrographical feature of the pale brown rock salt owed to the presence of celestine $\left(\mathrm{SrSO}_{4}\right)$. That strontium mineral was re-examined, using X-ray powder data, and scanning microscope observations, with EDS analysis.

The investigated rock salts exhibited a mineral association of halite (main component), anhydrite, celestine, calcite, gypsum, clay materials, iron compounds and a small amount of bitumen. In terrigenous sediments and the insoluble part of salt occurred higher content of strontium that in halite. Celestine crystals were observed in two forms: elongated platy crystals, forming fan-shaped aggregates and granular aggregates, strongly associated with anhydrite. On carbonate and sulphate strontium usually appearing as needle shaped aggregates of celestine. No barium minerals were observed.

The development and paragenesis of celestine suggested a post-sedimentary origin of these rocks that ought to be connected with diagenetic processes. An important observation that confirmed that thesis was the transformation of fine crystalline anhydrite into platy crystals, recrystallization and primary accumulation of strontium, as a result of evaporation processes.
\end{abstract}

Keywords: rock salt, Badenian, Wieliczka, strontium, celestine, geochemistry

\section{INTRODUCTION}

During the inspection of the workings at Level II of the east section of the Wieliczka salt deposit in the 1960's, brownish-pink salt was found in one of the chambers. The formation was clearly distinct in colour on the background of the typically gray surrounding salt rocks. The brownishpink and pale brown salt formed a large boulder, later classified as the Oldest Salt by J. Wiewiórka (Wiewiórka 1973). The studies conducted at that time indicated increased strontium and barium content in salt (Prochazka et al. 1969). Similar types of salts were observed mainly in the east section of the deposit. It was established at the early stage of studies that this kind of salt did not match the surrounding formations and displayed clearly diverse properties and chemical composition.

The purpose of this paper was to collect all of the available data on the so-called strontium and barium salts and present the results of our new studies completed last year. The main assumptions of this study consisted in the verification of the old data and confirmation of previous hypotheses on the formation of the type of salt 
in question, using currently available research methods. To explain the origin of the increased strontium content in salt, the researchers conducted proper analyses and compared the collected samples with those of dolomite salts that occur in the boulder sections of the Wieliczka salt deposit.

\section{LOCATION}

The Wieliczka salt deposit is situated in southern Poland, within the Carpathian Foredeep basin, among the folded Miocene sediments in the Carpathian orogenic front (Fig. 1). The Wieliczka salt deposit shows the shape of a strongly elongated ellipsis whose longer axis runs W-E, with the length of ca. $7 \mathrm{~km}$, while the shorter axis is $\mathrm{S}-\mathrm{N}$ and about $1 \mathrm{~km}$ long.
Müller Gallery. The sampled salts occurred as a characteristic complex of pale brownish rock salts distinguished from the surrounding gray salts (Prochazka et al. 1969). Dolomite salt samples were collected at Level I, at the intersection of the Sielec Drift and the Kunegunda Gallery, 20 m away from the St. Kinga Shaft.

\section{GEOLOGICAL SETTINGS}

The rock salts extracted from the Wieliczka Salt Mine belong to the Wieliczka Formation that was recognised as a Miocene (Badenian) salt series, deposited on a large area of the Carpathians. The Wieliczka Formation is spread over the territories of Poland, Ukraine, Slovakia, and Romania (Garlicki 1979, Peryt 2006, Bukowski 2011), as well as Hungary (Báldi et al. 2017).

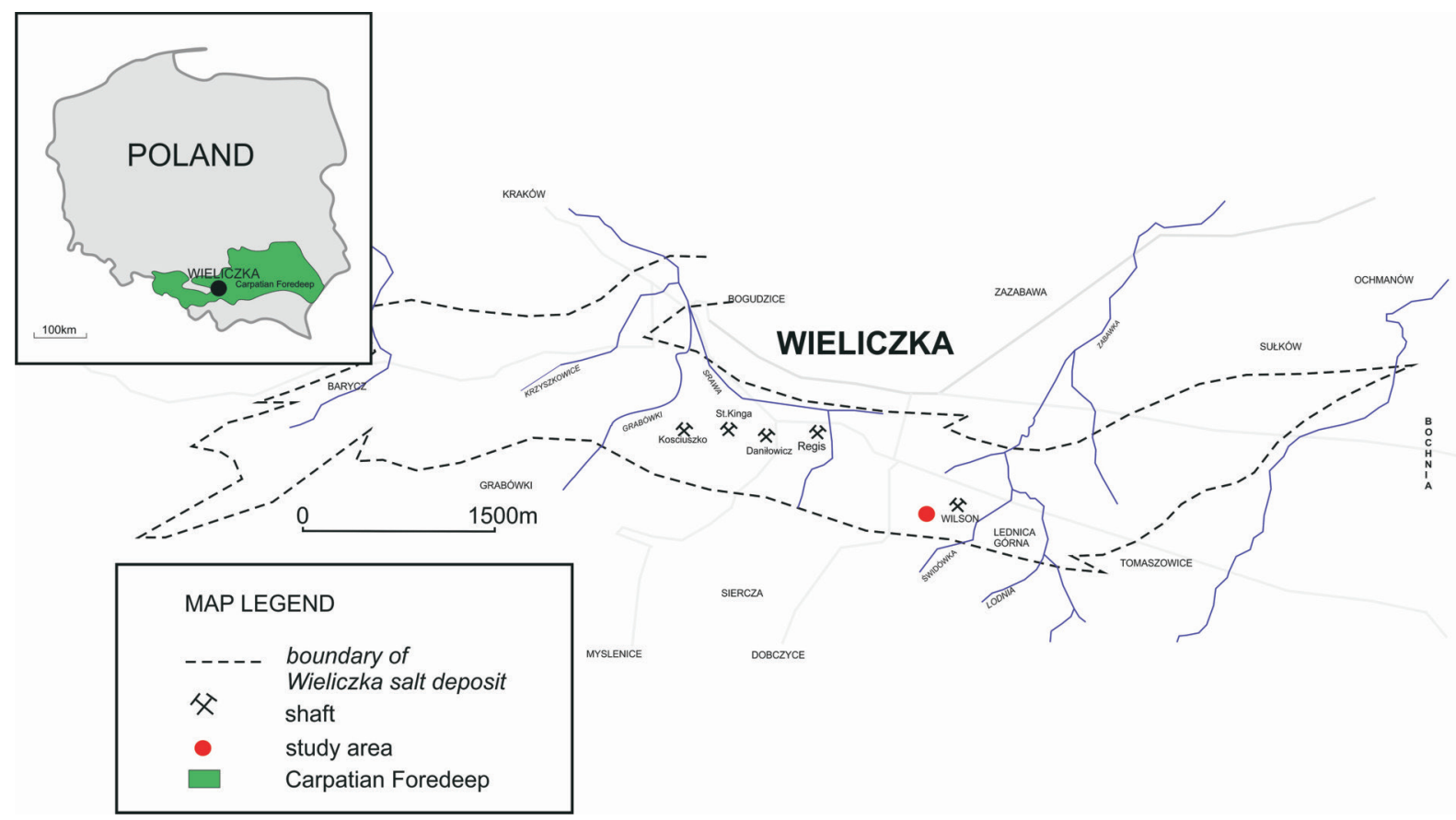

Fig. 1. Location of the research area

The object is the pale brownish salts, with increased strontium and barium contents (after Prochazka et al. 1969), as well as dolomite salts. Samples were collected from Chamber 3/307 at Level III, at the depth of ca. $140 \mathrm{~m}$ under the ground level, about 1,800 m east of the St. Kinga Shaft (Fig. 1). That location was close to the Karol Marek Incline, ca. $50 \mathrm{~m}$ east of the Franciszek
The Wieliczka Formation constitutes a relatively small section of the Miocene marine sediments and is closely associated genetically with the geological structure of the area. Theformation was created about 13.6 million years ago (Dudek et al. 2004, de Leeuw et al. 2010) during the socalled Badenian salinity crisis (Peryt 2006, Bukowski 2011). 
The present shape of the deposit was formed as a result of complex syn-sedimentation (Kolasa \& Ślączka 1985) and tectonic processes (Gawel 1962). The present shape of the deposit was formed as a result of complex syn-sedimentation (Kolasa \& Ślączka 1985) and intensive tectonic movements and the overthrust of the Carpathians on the Miocene deposits, the most significant processes that were responsible for the deposit's shape included folding, overthrust, and layer softening (plastification) (Prochazka et al. 1969). Those processes finally affected the original arrangement of evaporites. with the deformation and fracturing of original layered structure (Fig. 2). The final stage of the current salt deposit shaping took place during the period of erosion and modelling of its top surface. Uncovered surfaces were subjected to intense transformations, creating the so-called silt-andgypsum cap (cap rock). This process continued until the Pleistocene when the ice sheet advanced onto the deposit areas, and the open parts of the salt deposit were covered in a gigantic ice sheet.

In the Wieliczka Salt Mine, the lower, layered, and upper boulder deposits were distinguished.
The beds constituting the lower part (stratiform) with evaporitic character are strongly tectonically affected. They create elongated scales, separated by terrigenous formations. However, the upper section contains salt boulders (breccia) of various sizes, mixed within claystones and clay-salt rocks (Zuber). Macroscopically, three salt varieties are identified in the boulder section of the deposit: typical laminated green salt, coarse-crystalline stained-glass salt, and dolomite salt (Pawlikowski 1978). Such boulders often occur in reverse or rotated positions.

The salt boulder with strontium and barium, located in the research area (Fig. 3), had probably been a piece of original thick rock salt bed that was cracked and relocated as a result of tectonic movements. In contrast to the surrounding zuber and claystone rocks that were deformed plastically, the salt block behaved as a rigid boulder and preserved its original internal structure (Alexandrowicz 2000, Prochazka et al. 1969).

The salt boulders are surrounded by heavily cracked and lustered claystones, and the contacts between them are irregular. Thin layered deposits of stratiform green salt, shaft salt, and Spisa salt are found east of the boulders.
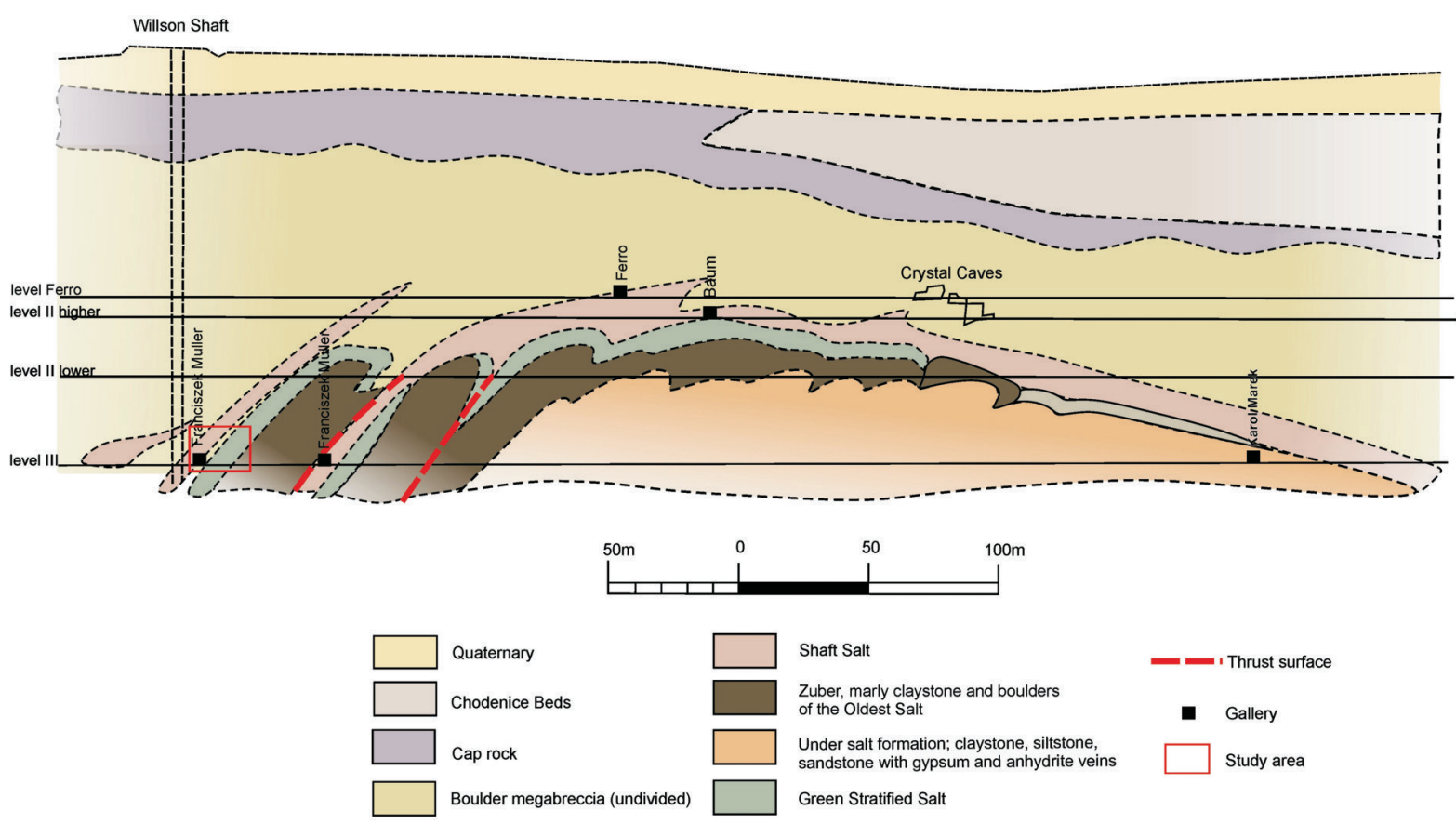

Fig. 2. Geological cross-section of the Wieliczka salt deposit, along the +284055 meridian (based on Gawet 1962, Alexandrowicz 2000 and the mining maps of the Wieliczka Salt Mine) 
On the north side of the salt boulder, about $20 \mathrm{~m}$ south of the Franciszek Müller Drift II (Fig. 3), the occurrence of wedged blocks of sandstones and mudstones separated from the undersalt sandstone beds was identified.

The rock salt reminding of green salt (but with distinctly larger halite crystals and clearly macroscopically visible a large type proportion of carbonates), is situated between sandstone and mudstone blocks and the pale brown salt layers (or those of salt with strontium and barium).

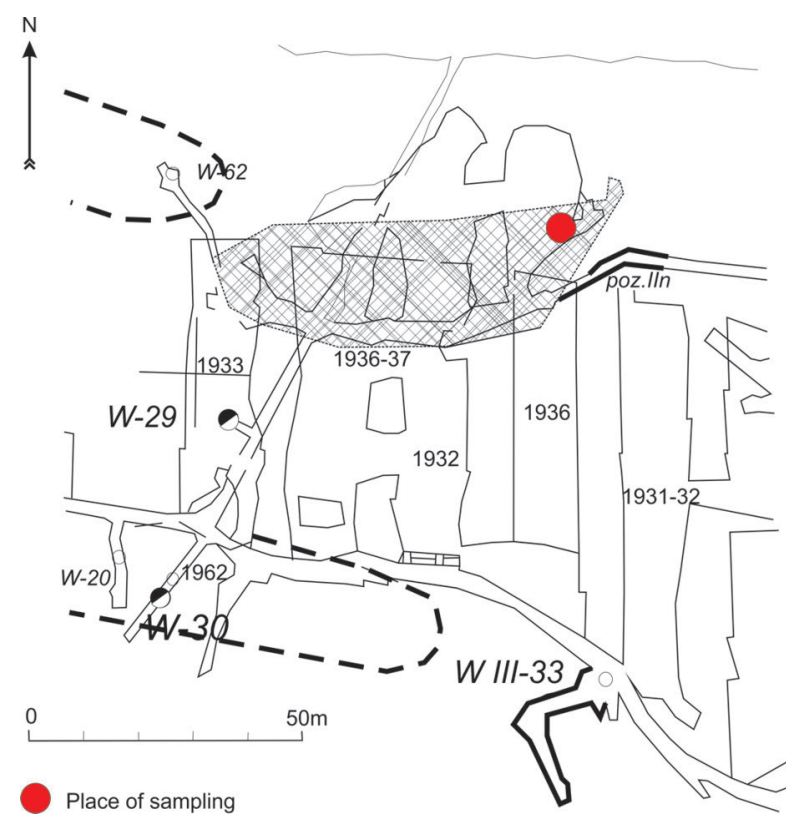

Fig. 3. Research area at Level III, near the Karol Marek Incline and the Franciszek Müller Drift (based on Gawet 1962, Prochazka et al. 1969 and the mining maps of the Wieliczka Salt Mine)

Normal sequences of Green salt, interbedded with claystones, Shaft salt, and Spisa salt, occur farther to the north of the Franciszek Müller Drift II (Fig. 4). After a detailed analysis of the neighbouring cross-corridors and drifts, it was possible to identify a similar separation east of the chambers that had been previously studied and at Level $\mathrm{V}$ of the same location in the deposit. It should be highlighted that the salt boulder in question is located within a layered section of the deposit and it can be stated, on the basis of geological relationships and the shoal arrangements, that the boulder is reversed in respect of its original location.

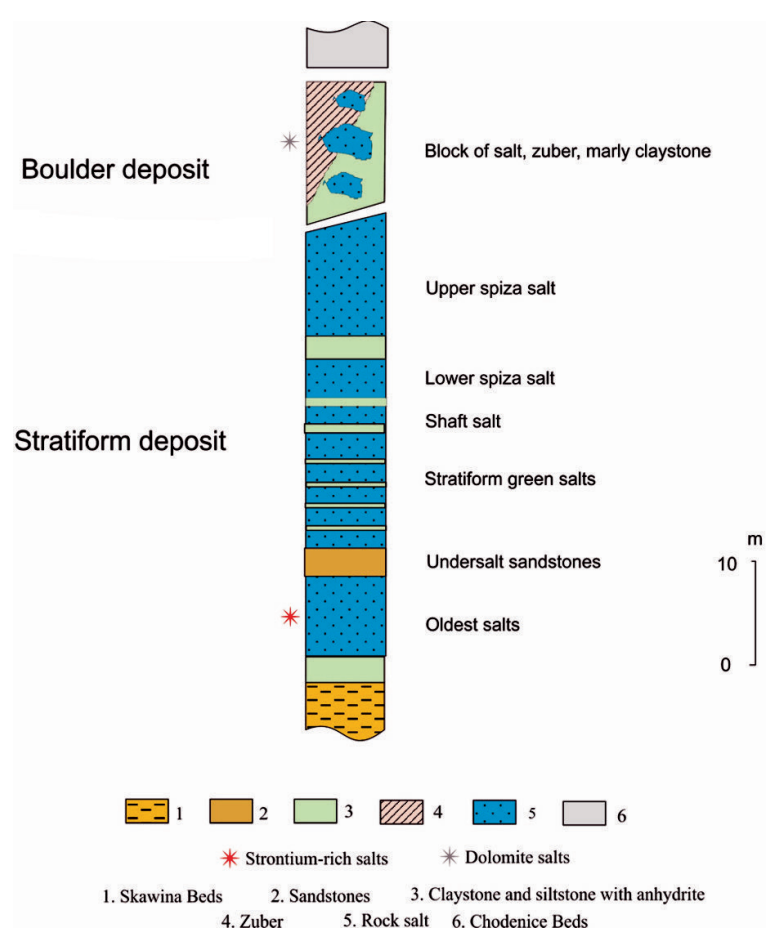

Fig. 4. The lithostratigraphic column of the Wieliczka salt series (after Wiewiórka 1973, Garlicki 1979), with indication of strontium-rich and dolomite salts

\section{METHODOLOGY}

The studies concentrated on evaporitic rocks belonging to the brownish salt with strontium and barium separation at Level III and the dolomitic salts at Level I. Brownish salt samples collected from Chamber 3/307 of Level III and dolomitic salt samples collected from the east section of the corridor wall, at the intersection of the Sielec Drift and Kunegunda Corridor, were used in our analysis. Samples were cleaned and described, with drafting of the photographic documentation of the rocks on a macroscopic scale.

The brownish salt samples from Level III, weighing $5 \mathrm{~kg}$, were dissolved in 201 of bi-distilled water by means of the gravitational method. Next, the brine was drained until any reaction with $5 \%$ $\mathrm{AgNO}_{3}$ disappeared. To improve the quality of fraction separation, the samples were additionally separated by ultrasound. The residue, received as a result of rock salt purification in water, was decanted, dried at room temperature $\left(24-25^{\circ} \mathrm{C}\right)$, and weighed on a technical scale, with the accuracy of $0.01 \mathrm{~g}$. That allowed us to calculate the percentage proportions of insoluble parts, in respect to the original sample weight. 
The dolomite salt samples collected at Level I, weighing $313 \mathrm{~g}$, were dissolved in $5 \mathrm{l}$ of demineralized water by means of the gravitational method. Next, the brine was drained until any reaction with $5 \% \mathrm{AgNO}_{3}$ disappeared. After dissolving, the final sample constituted an averaged mass of several samples collected within the same separation. Since only two significant fractions could be identified in the undissolved residue, the sample was not separated into fractions like it happened in the previous case.

As to the detailed studies, observations were conducted, using a Motic SMZ-168-BL stereoscopic microscope. During those tests, single anhydrite crystals, with interesting ingrowths and forms, were separated from the $0.5-2 \mathrm{~mm}$ fraction for further analysis.

The studies with a FEI Quanta 200 FEG scanning microscope allowed to obtain the images of single crystals, with their ingrowths, and to determine the preliminary chemical composition of both background and ingrowths being tested, with the application of the EDS analysis. The selected Samples: K1 (<0.008 mm); K2 (0.5-2 mm); and $\mathrm{K} 3(>2 \mathrm{~mm})$ were subjected to an XRD analysis, with the use of a PHILIPS X'PERT PW 1729 Xray diffractometer, with a reflective graphite monochromator ( $\mathrm{Cu} \mathrm{Ka}$ radiation).

\section{ROCK CHARACTERISTICS}

Pale brown salt from Level III, subjected to our studies, represents rock salt with diverse colours, mineral compositions, and structures (Fig. 5A, B). Accompanying gangue contained primarily terrigenous pelitic material, occurring in the form of interbedding. Such rocks are polymineral, in pelitic fraction, and often mixed with fine halite crystals. The gangue was clearly distinguished on the background of halite, creating thin laminae, up to $10 \mathrm{~cm}$ thick, or $2 \mathrm{~cm}$ on the average (Fig. $5 \mathrm{C}$ ), with diverse colours (gray, dark gray, and often brownish). Intense interbedding of halite and terrigenous rocks was observed locally.
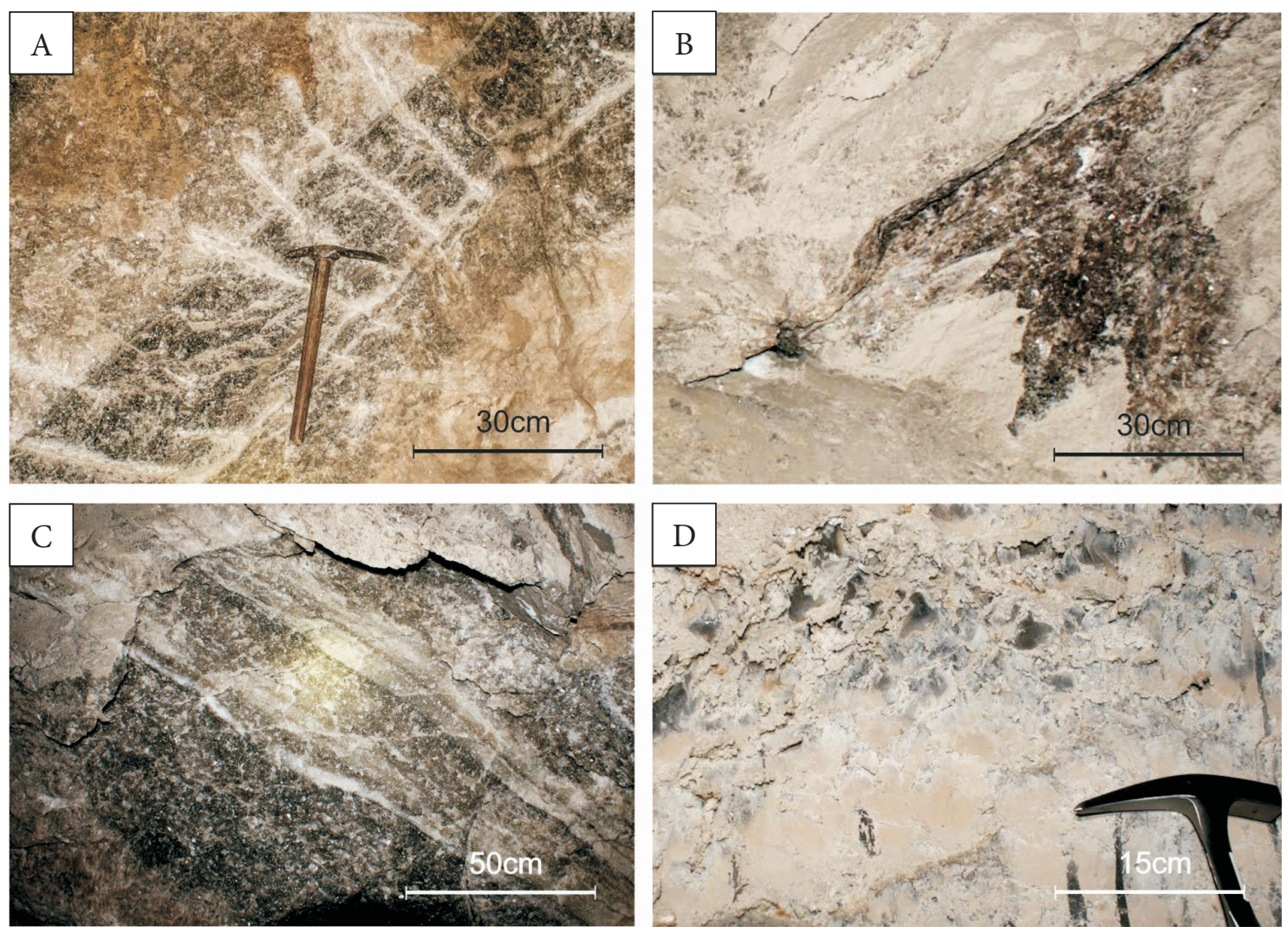

Fig. 5. Occurrence of strontium-rich salt and dolomite salt in the Wieliczka salt deposit: A) clearly visible layers of the salt boulder; B) a wall fragment showing salt, with the specific brownish-red colour; C) fine laminated rock salt with terrigenous material (location: Level III, about 1,800 m east of the St. Kinga Shaft); D) dolomite salt, with irregular structure; halite crystals overgrown with terrigenous pelitic sediments are visible (location: 20 from the St. Kinga Shaft, Level II) 
In the terrigenous rocks (Fig. 5C), the pelitic fraction is composed of carbonates (positive $\mathrm{HCl}$ tested) and the silt material contains quartz. Microscopic observations revealed single feldspars, anhydrite, and gypsum crystals, in addition to quartz (Fig. 6A, B)

The rock salts of the salt boulder did not constitute a uniform mass. Part of deposit coul identify salts by various colours, grain sizes, and internal halite formations. Primarily, two types of salts could be distinguished: gray salt laminated with terrigenous material and brownish-pink salt, with disordered a texture. Laminated rock salts (sample SK1) were characterised by the repetition of lamina sets, composed of a layer of terrigenous material, medium-sized halite crystals, and large halite crystals, with the layers of nodular anhydrite. The first bottom layer $\mathrm{H} 1$ consisted of terrigenous pelitic material, with fine halite crystals, gray or brownish, locally wedged or thickened.

Above the terrigenous material there occurred a halite layer H2, with large xeromorphic halite specimens. Those crystals were transparent at their edges as a result of crystallisation, and milky or turbid inside, preserving the original zonal structure of the crystals. Additionally, microscopic observations confirmed the presence of liquid and gas inclusions (Fig. 7). Small veinlike concentrations of silt and terrigenous material were found between the halite crystals. The structure and composition of those veins were the same as those of the layers below. The third layer H3 (Fig. 8) was composed of xeromorphic and isometric halite crystals, of a snow white colour and without ingrowths or distinct discolouration, representing large-crystal structures.
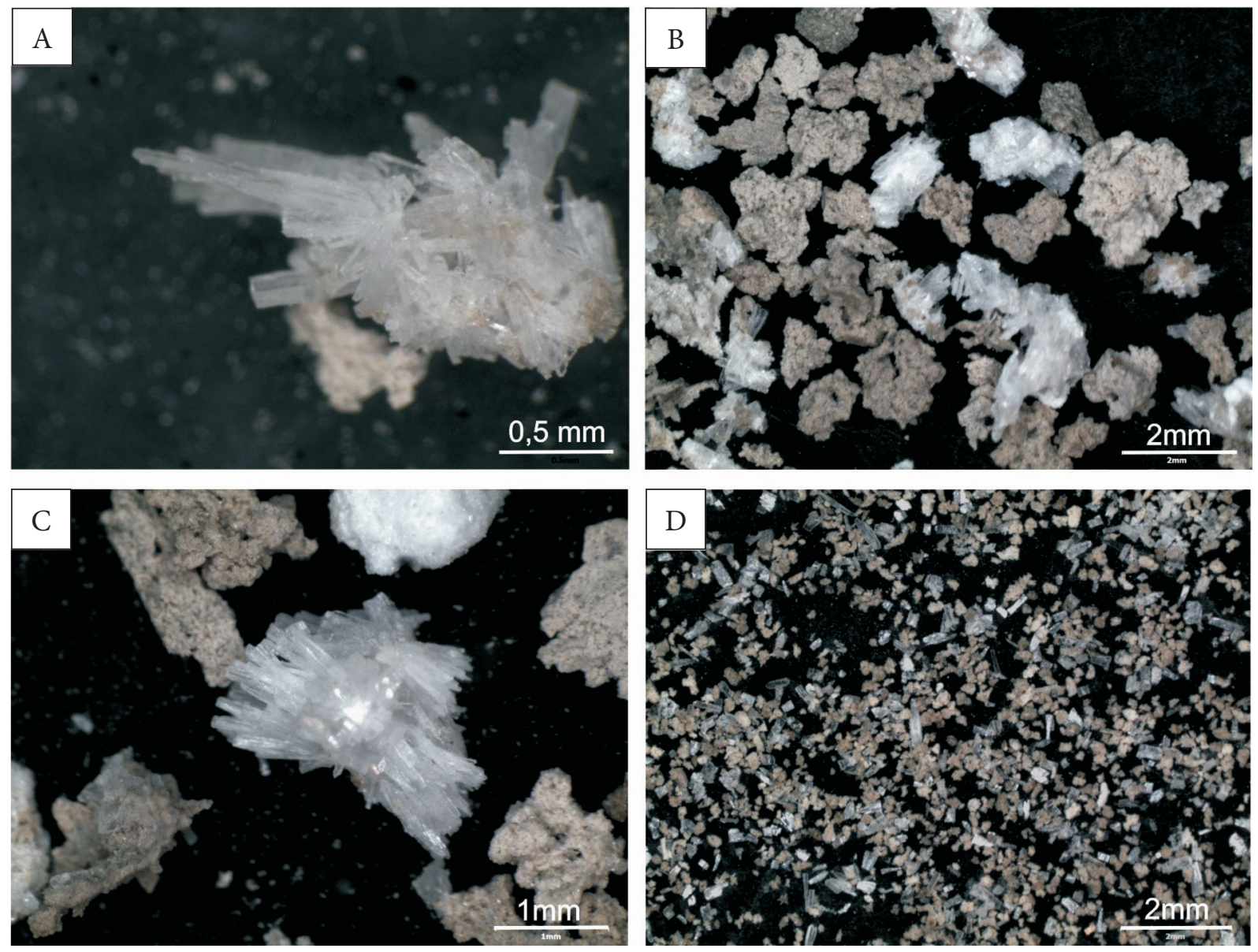

Fig. 6. A microscopic image of particular mineral fractions, with the identification of main minerals. The photograph was taken under a binocular magnifying glass: A) large overgrown gypsum crystals; B) image of 0.5-2 $\mathrm{mm}$ fractions, large anhydride crystals and insoluble collapsible pelitic fraction; C) an image of two types of anhydrite as a fully formed crystal and a clumsy, finegrained clump of anhydrite; D) the whole image of insolube crystals-mix of gypsum, anhydrite and pelitic fraction 

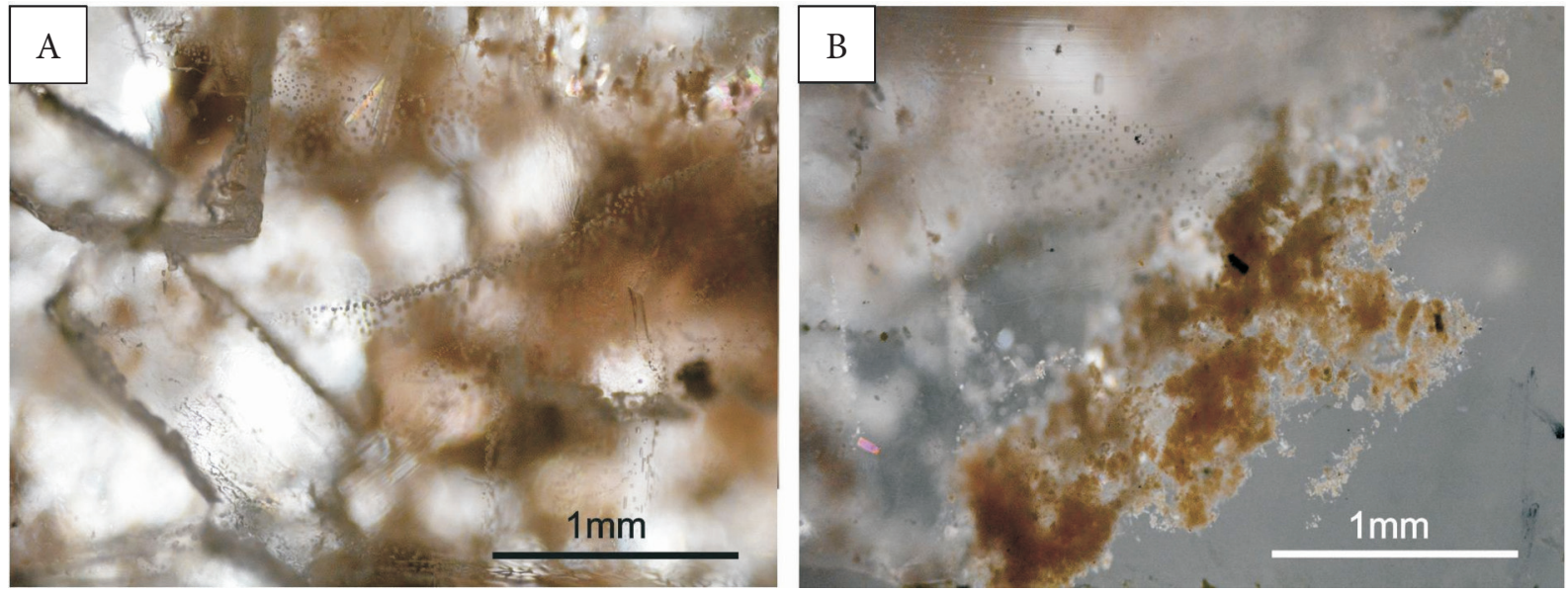

Fig. 7. A microscopic image of terrigenous material in dispersion: A) between crystals of anhydrite and halite indicate with inclusion group, magnification $20 \times ; B$ ) as a compact mass, the background is the group of inclusions in halite crystals, magnification $5 \times$

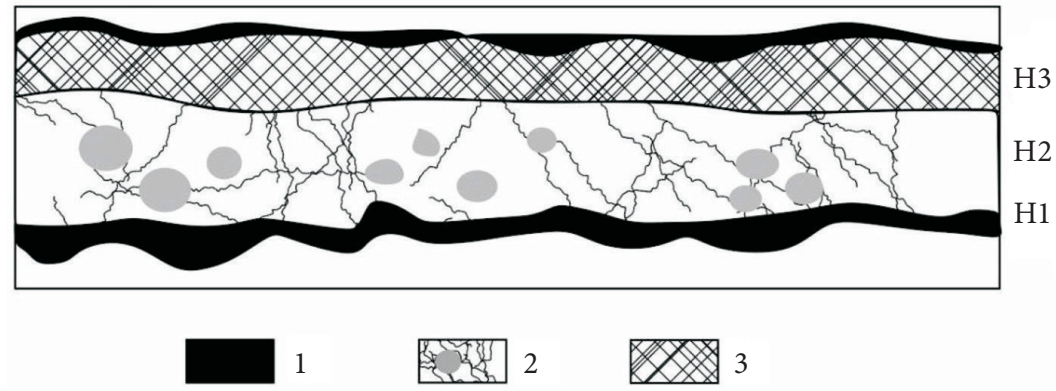

Fig. 8. Sketch of the internal structure of laminated salt from Chamber 307/3, Level III: 1 - terrigenous pelitic material, with fine halite crystals, 2 - large xeromorphic halite specimens, with small vein-like concentrations of silt and terrigenous material, 3 - xeromorphic and isometric halite crystals, with snowy white large-crystal structures

They lacked zonal structure, as it was the case of the lower layers. Terrigenous material covers the layer top.

Non-layered rock salts (sample SK2) represented a uniform structure of the whole rock mass, without delamination. Terrigenous material is dispersed within the rock (Fig. 7A, B) built veins and concentric clusters. Anhydrite was developed in the form of gray or gray-blue concretions (nodules), ingrown between large halite crystals. Particular halite crystals were large or even very large (up to $5 \mathrm{~cm}$ ), isometric, anisometric, or xeromorphic. They had a zonal internal structure (Fig. 9A, B). Large halite crystals were bound by fine crystal specimens. The colours of non-layered rock salt were diverse in saturation and they depended on the quantity of terrigenous material concentration. Exceptionally large halite crystals, with a distinct zonal structure, were transparent on sides and milky white inside. Similarly to previous layers, those salts also reacted (although poorly) with $\mathrm{HCl}$ which indicated some admixture of carbonates.

Locally, non-laminated salts could also be distinguished, with distinct and large concentrations of terrigenous material. Those salts displayed the most intense colours among all the previously mentioned specimens (sample SK3). The salts were non-layered, with large and zonal crystals, interlaced with anhydrite and terrigenous material ingrowths. Terrigenous minerals were partly brownish, beige, or stained by which the salts obtained intense colours. The reaction with $\mathrm{HCl}$ was rapid which clearly indicated the abundant presence of carbonates that could easily be distinguished macroscopically. In comparison with the previously mentioned layers, they represented exceptionally pure composition. When hammered, they released salts of a type with an unpleasant bituminous smell. 

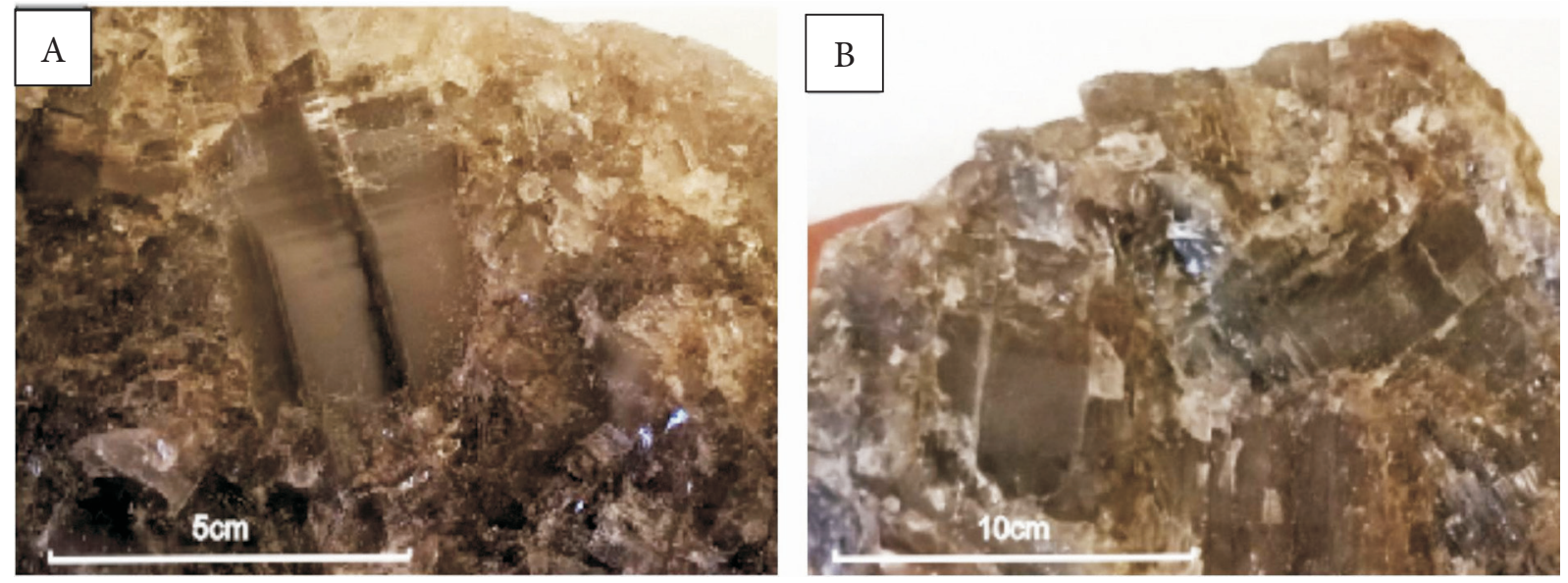

Fig. 9. Salts without overgrowths, non-layered, with intense brownish colour and bituminous smell, sample SK2, Wieliczka, Level III: A) fragment of the primary halite texture; B) image of a sample with coarsely halite crystals with preserved primary textures

To compare the compositional anomalies or confirm similarities, dolomite salts were subjected to additional verification tests since previous tests had indicated increased strontium contents, with a large proportion of silt material (Fig. 5D). The specimens in question can be described as contained the medium-sized or large-size halite crystals. Single specimens or large clusters of halite crystals were ingrown into the compact gray mass of calcium carbonate, silt, anhydrite, and pelitic terrigenous material. The proportion of undissolved material of the given separation amounted to as much as $22 \%$.

\section{RESULTS}

The investigations were focused on two sample sets. The first is typical for the non-layered salts representing the most intense colours, uniform internal structure (sample SK3, 2, K4) with distinct terrigenous material and carbonate concentrations. The second sample set represents the dolomite salts of Level I for comparison.

Sample K2 contains insoluble parts of salt, with strontium in the fraction of $0.5-2 \mathrm{~mm}$ (Fig. 6AC), while Sample K4 represents the material of the whole rock (non-layered salts). Sample KD1 contains fragments of the averaged dolomite salt of Level I. Sample KD2 represent the results of the insoluble residuum of those salts in all fractions.

Celestine was distinct in the microscopic image, owing to its diverse form of occurrence in respect of that of the background minerals. Celestine often developed mono-crystals with rhombic symmetry, usually plate crystals, according to [001], pillar crystals, and crystalline brushes. The mineral also occurred in compact and grain forms. Celestine plates were elongated in axes $x$ or $y$ and ended with the typical crystal cut in their upper parts. The crystal wall coefficients were discussed in [001], [110], [011], [102]. Celestine showed poor pleochroism. It was distinguished on the anhydrite background by a stronger relief, poor birefringence, and clear pillar cleavage (Fig. 10C, D).

A clear bright colour of celestine, visible in the scanning microscope with a BS attachment, allowed the easy identification of the mineral. In the samples collected from SK3, celestine usually created either needle aggregates on carbonate concentrations (Fig. 10A, B) or it filled anhydrite voids. Their size was mostly $0.03-0.06 \mathrm{~mm}$. Single specimens reached more than $0.2 \mathrm{~mm}$. Based on the observations under a SEM microscope and the transmitted light plates, it was possible to identify two types of celestine: distinctly elongated plates, creating fan-rosette aggregates (Fig. 10C), autoor hypo-automorphous specimens, quite strongly elongated, according to [100], adhering along the longer edges to form fans and xenomorphs, isometric specimens, adhering along the shorter edges to form brushes (Fig. 10D). They either occur mainly on carbonate grain or grew on anhydrite (Fig. 10A, D). 

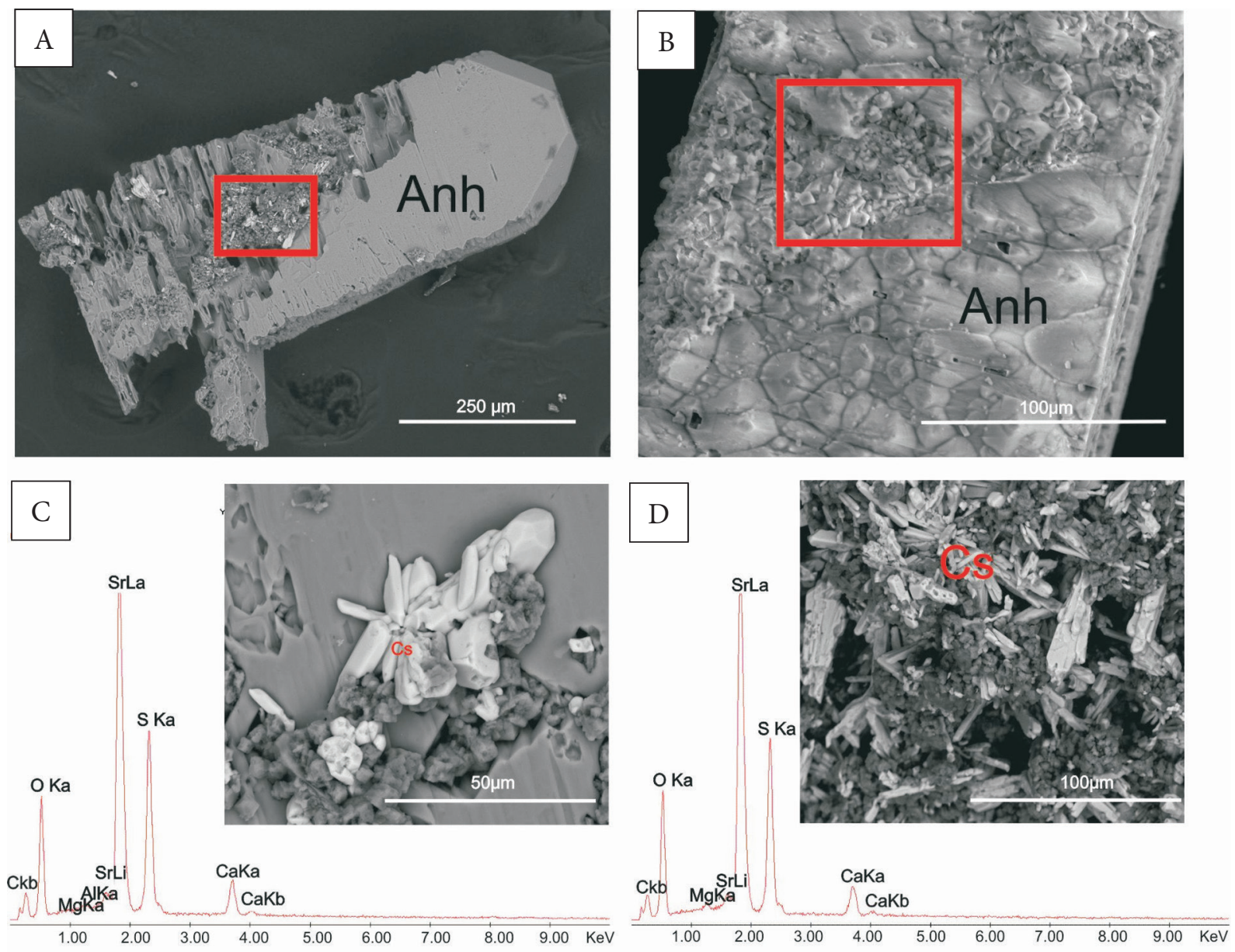

Fig. 10. Photos of brownish salt with strontium from the Wieliczka Salt Mine, taken by a scanning microscope, with a BSE mode: A) a single crystal of anhydrite with accumulation of strontium minerals; B) cracked and disolved surface of anhydrite, with accumulation of celestine crystals; C) magnification of fan-rosette celestine aggregates on anhydrite surface, with diagram of chemical analysis(in frame); D) a concretion of needle aggregates of celestine crystals (Cs), with SEM-EDS analysis below

Anhydrite occurred either as separate concentrations or as single rectangular specimens fixed in halite (Figs. 6C, D, 11A, B). It often created mineral overgrowths, together with celestine. Large plate specimens, with rhombic symmetry, were noticeable, mostly with a large number of voids filled with celestine. Such specimens were from 0.3 to $1 \mathrm{~mm}$ large and often occurred in twin forms and indicated a strong flattening in the direction of axis $y$ (Strunz 1966), with strong elongation in the direction of axes $x$ and $z$. The plate-shaped halite crystals most often grew out of the fine crystalline centres of terrigenous material, in the direction of halite mass, or otherwise created independent plate specimens, often overgrowing each other (Borkowska \& Smulikowski 1973). The gypsum that occurred commonly, especially in insoluble materials, was less often observed in thin cut sections. The mineral created xeno- and automorphous concentrations, isolated in halite, as well as single brush concentrations (Fig. 6A). One could see gypsum in thin cut sections, mainly in cracks and in the form of fully developed minerals, twin forms, and brush growths. Gypsum represented a poor negative relief and birefringence. The gypsum sample extinguished light when tilted

Identification of calcite and other carbonate minerals was quite difficult owing to their fine crystalline form. During further tests, with the use of the X-ray method, the occurrence of dolomite was also identified. Most often, the minerals created various forms of concentrations among the halite crystals; usually irregular and asymmetric, forming lumps or veins. 
The presence of celestine was additionally confirmed by the analysis of the X-ray phase of samples $\mathrm{K} 1, \mathrm{~K} 2$, and $\mathrm{K} 3$. The results were compared to the model values for network separations regarding celestine, in accordance with the respective table
(Michejew 1957). Adequate compliance of peaks in the samples confirmed the occurrence of celestine, dolomite, and anhydrite. Celestine occurred jointly with carbonates. The peaks of the basic minerals were similar in three samples (Fig. 12).
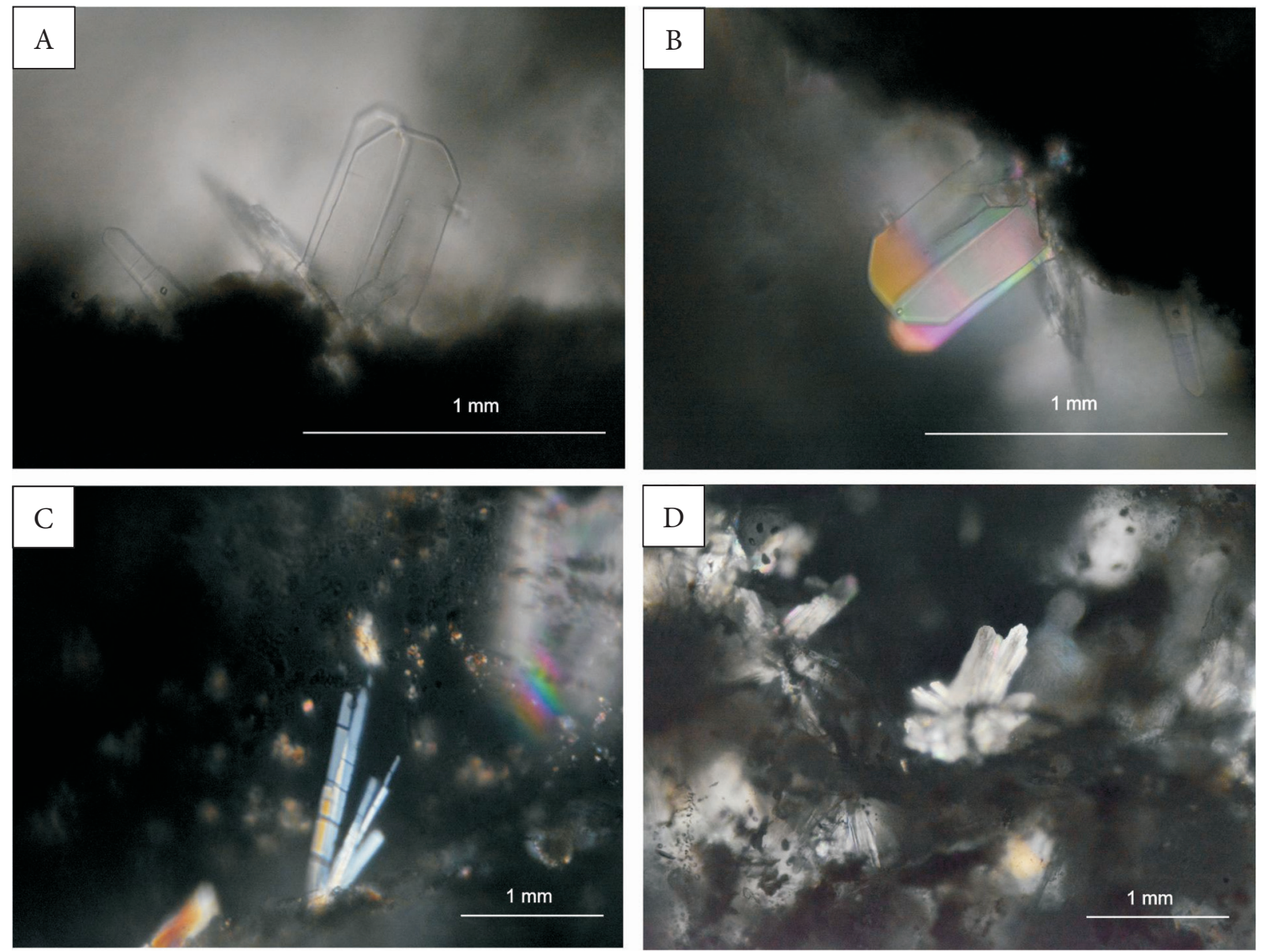

Fig. 11. A microscopic photograph of brownish salt with strontium from the Wieliczka Salt Mine, taken in transmitted light: A) a group of crystals of anhydrite, PPL, magnification 50×; B) anhydrite crystals, XPL, magnification 50×; C) needle aggregates of celestine crystals, XPL, magnification 20×; D) fan-rosette celestine aggregates(centre), XPL, magnification 20×

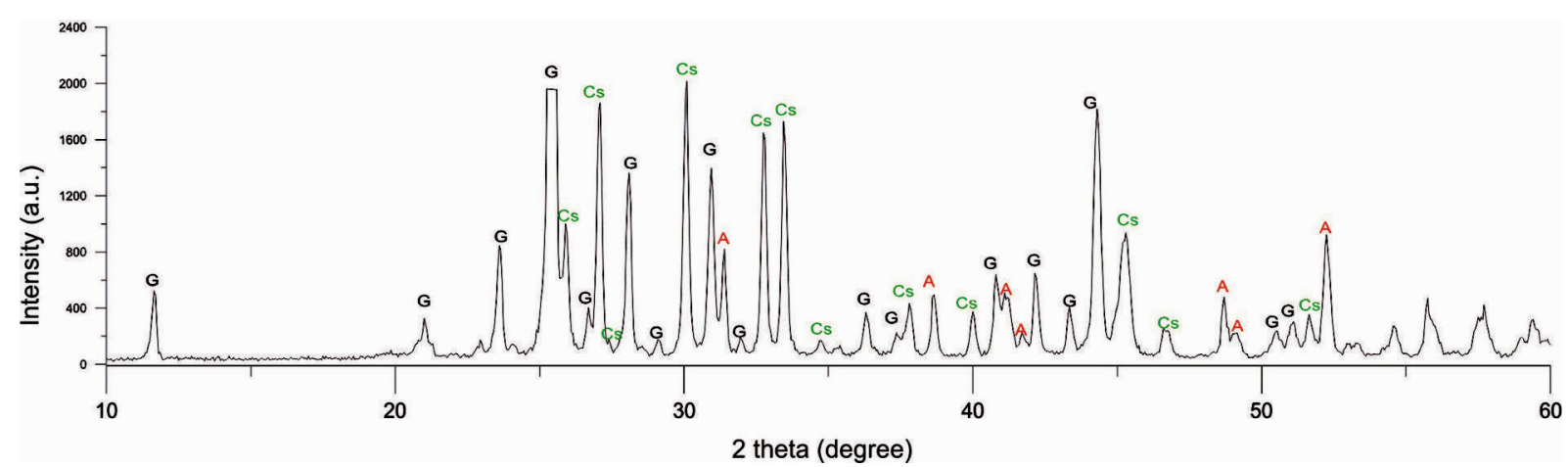

Fig. 12. Diagram of qualitative interpretation of the tested samples (K1), with the use of X-ray spectroscopy: A - anhydrite;

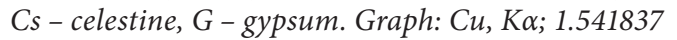




\section{DISCUSSION}

Strontium is quite common in the rocks of the earth's crust (Wedepohl \& Turekian 1961); nevertheless, strontium minerals are rather rare. Strontium occurs mainly in the form of isomorphous dispersion (Noll 1934, Turekian \& Kulp 1956). Primary strontium minerals in evaporates develop only and exclusively during seawater evaporation (Zherebtsova \& Volkova 1966), while secondary ones in the processes of physical and chemical transformations of the minerals from the groups of sulphates and carbonates, such as gypsum, anhydrite, and transformations of marls. Free strontium is released to the environment as a result of such transformations. Strontium starts to develop its own new mineral, celestine, or less often strontianite $\left(\mathrm{SrCO}_{3}\right)$.

In carbonate rocks (e.g. limestone), the Sr to Ca ratio proportion is fairly low (Usdowski 1973) and limited by a poor possibility of Sr incorporation into the calcite crystal lattice. Only aragonite represents a type of network being similar to that of strontianite and that is why it can contain up to several percent of Sr. In salt deposits, only calcite is the primary and stable phase (Noll 1934). Dolomites generally display lower values of strontium than limestones and that is associated with a considerably lower proportion of $\mathrm{CaCO}_{3}$ (Müller 1962).

Strontium is bound primarily with gypsum and anhydrite in sulphate rocks. The proportions of those minerals in salt rock are quite high (Usdowski 1973) and they often influence the chemical composition of the salt deposit. However, it is necessary to determine whether we are dealing with primary or secondary gypsum in a particular deposit. Secondary gypsum, created as a result of the intake of water from the environment, contains lower quantities of strontium than the surrounding anhydrites (mainly based on the fact that the molecular mass is higher than in the anhydrite due to the 2 moles of $\mathrm{H}_{2} \mathrm{O}$ in the gypsum). The process can run in a reverse direction when gypsum is dehydrated (Herrmann 1961). Silt sediments, however, often get enriched with strontium as a result of absorption (Turekian \& Kulp 1956).

\section{CONCLUSIONS}

The whole tested salt samples definitely demonstrate increased strontium content, exceeding the average content of that element found in the rock salt separations. Chemical and microscopic tests were unable to confirm the increased barium content that had been clearly indicated in previous research (Prochazka et al. 1969). In addition, the occurrence of dolomite and anhydrite was identified in large quantities which significantly affected the chemical composition of the salt samples being tested. The brownish colour of salt was associated with the occurrence of dispersed pelitic material, with iron hydroxides that occurred in the form of irregular concentrations.

In the case of the Wieliczka brownish salts, we are probably dealing with two generations of celestine: the primary generation formed during brine evaporation, and the secondary generation developed as a result of the release of excess strontium by sulphate rocks, in the processes of physical and chemical transformations, also associated with dispersed carbonate material.

I would like to thank Dr Krzysztof Bukowski and Dr Tomasz Tobola for their expert advice and encouragement throughout this project. I would also like to thank the reviewers for their relevant comments and help.

This work was financially supported by the AGH University of Science and Technology, research projects No 11.11.140.320.

\section{REFERENCES}

Alexandrowicz Z., 2000. Zarys budowy geologicznej wielickiego złoża soli. [in:] Alexandrowicz Z. (red.), Groty Kryształowe w Kopalni Soli Wieliczka, PAN IOP, Kraków, 11-19.

Báldi K., Velledits F., Ćorić S., Lemberkovics V., Lőrincz K. \& Shevelev M., 2017. Discovery of the Badenian evaporites inside the Carpathian Arc: implications for global climate change and Paratethys salinity. Geologica Carpathica, 68, 3,193-206.

Borkowska M. \& Smulikowski K., 1973. Minerały skałotwórcze. Wydawnictwa Geologiczne, Warszawa.

Bukowski K., 2011. Badeńska sedymentacja salinarna na obszarze między Rybnikiem a Dębica $w$ świetle badań geochemicznych, izotopowych $i$ radiometrycznych. Rozprawy, Monografie - Akademia Górniczo-Hutnicza im. Stanisława Staszica, 236, Wyd. AGH, Kraków. 
Brudnik K., Przybyło J. \& Stecka J.,2000 Budowa geologiczna i warunki hydrogeologiczne rejonu Grot Kryształowych. [in:] Alexandrowicz Z. (red.), Groty Kryształowe w Kopali Soli Wieliczka, PAN IOP, Kraków, 35-58.

Dudek K., Bukowski K. \& Wiewiórka J., 2004. Datowania radiometryczne badeńskich osadów piroklastycznych z okolic Wieliczki i Bochni. [in:] Michalik M., Jacher-Śliwczyńska K., Skiba M. \& Michalik J. (red.), Datowanie minerałów i skat: VIII Ogólnopolska Sesja Naukowa, Kraków, 18-19 listopada 2004, Kraków, 19-26.

Garlicki A., 1979. Sedymentacja soli mioceńskich w Polsce. Prace Geologiczne - Polska Akademia Nauk. Oddział w Krakowie. Komisja Nauk Geologicznych, 119, Zakład Narodowy im. Ossolińskich, Wrocław - Kraków.

Gaweł A., 1962. Budowa geologiczna złoża solnego Wieliczki. [in:] Czaplicka J. et al. (red.), Czterdzieści lat Instytutu Geologicznego 1919-1959. Cz. 3, Prace - Instytut Geologiczny, 30, Wydawnictwa Geologiczne, Warszawa, 305-332.

Herrmann A.G., 1961. Zur Geochemie des Strontiums in den salinaren Zechsteinablagerungen der StassfurtSerie des Südharzbezirkes. Chemie der Erde, 21, 137-192.

de Leeuw A., Bukowski K., Krijgsman W. \& Kuiper K.F., 2010. Age of the Badenian salinity crisis; impact of Miocene climate variability on the circum Mediterranean region. Geology, 38, 8, 715-718.

Kolasa K. \& Ślączka A., 1985. Sedimentary salt megabreccias exposed in the Wieliczka mine, Fore-Carpathian Depression. Acta Geologica Polonica, 35, 3-4, 221-230.

Mikheyev V.I., 1957. Rentgenometricheskiy opredelitel' mineralov. Gosudarstvennoyenauchno-tekhnicheskoye izdatel'stvo literatury po geologii i okhrane nedr, Moskva [Михеев В.И., 1957. Рентгенометрический определитель минералов. Государственное научно-техническое издательство литературы по геологии и охране недр, Москва].
Müller G., 1962. Zur Geochemie des Strontiums in ozeanenEvaporiten unter besonderer Berücksichtigung der sedimentären Coelestin lagerstätte von Hemelte-West (Süd-Oldenburg). Geologie, 35,1-90.

Noll W., 1934. Geochemie des Strontiums. Chemie der Erde, 16, 507-600.Prochazka K., Wala A. \& Wiewiórka J., 1969. Sole kamienne ze strontem i barem $w$ złożu solnym Wieliczka. Prace Mineralogiczne, 9218, Wydawnictwa Geologiczne, Warszawa.

Strunz H., 1966. Mineralogische Tabellen. Akademische Verlags-Gesellschaft.

Turekian K.K. \& Kulp J.L., 1956. The geochemistry of strontium. Geochimica et Cosmochimica Acta, 10, 245-296.

Turekian K.K. \& Wedepohl K.H., 1961. Distribution of the Elements in some major units of the Earth's crust. Geological Society of America, 72, 175-192.

Pawlikowski M., 1978. Badania petrograficzne złoża solnego Wieliczki(Petrographic studies on the Wieliczka Salt Deposit). Prace Mineralogiczne, 58, Zakład Narodowy im. Ossolińskich, Wrocław - Kraków, 65-124.

Peryt T., 2006. Sedymentacja ewaporatów badeńskich w zbiorniku przedkarpackim. Przegląd Geologiczny, 54, 438-444.

Usdowski E., 1973. Das geochemische Verhalten des Strontiums bei tier Genese und Diagenese von Ca-Karbonntund Ca-Sulfat-Mineralen. Contributions to Mineralogy and Petrology, 38, 1, 177-195.

Wiewiórka J., 1973. Poziom najstarszej soli kamiennej w pokładowym złożu solnym Wieliczki. Studia i Materiały do Dziejów Żup Solnych w Polsce, 3, 46-58.

Zherebtsova I.K. \& Volkova N.N., 1966. Experimental study of behaviour of trace elements in the process of natural solar evaporation of Black Sea and Sasyk-Sivash brine. Geochemistry International, 3, 656-670. 